\title{
Physiological features of Halomonas lionensis sp. nov., a novel bacterium isolated from a Mediterranean Sea sediment
}

\author{
Frédéric Gaboyer, ${ }^{a, b, c}$, Odile Vandenabeele-Trambouze ${ }^{a, b, c}$, Junwei Cao ${ }^{a, b, c}$, \\ Maria-Cristina Ciobanu ${ }^{a, b, c}$, Mohamed Jebbar ${ }^{a, b, c}$, Marc Le Romancer ${ }^{a, b, c}$, Karine Alain ${ }^{a, b, c,{ }^{*}}$
}

\begin{abstract}
a Université de Bretagne Occidentale (UBO, UEB), Institut Universitaire Européen de la Mer (IUEM) - UMR 6197, Laboratoire de Microbiologie des Environnements Extrêmes (LMEE), rue Dumont d'Urville, F-29280 Plouzané, France

b CNRS, IUEM - UMR 6197, Laboratoire de Microbiologie des Environnements Extrêmes (LMEE), rue Dumont d'Urville, F-29280 Plouzané, France

${ }^{c}$ Ifremer, UMR6197, Laboratoire de Microbiologie des Environnements Extrêmes (LMEE), Technopôle Pointe du diable, F-29280 Plouzané, France
\end{abstract}

\begin{abstract}
*: Corresponding author : Karine Alain, tel.: +33 (0)2 98498853 ; fax: +33 (0)2 98498705 ; email address : Karine.Alain@univ-brest.fr
\end{abstract}

\begin{abstract}
:
A novel halophilic bacterium, strain $\mathrm{RHS}^{\circ}{ }^{\top}$, was isolated from marine sediments from the Gulf of Lions, in the Mediterranean Sea. Its metabolic and physiological characteristics were examined under various cultural conditions, including exposure to stressful ones (oligotrophy, high pressure and high concentrations of metals). Based on phylogenetic analysis of the 16S rRNA gene, the strain was found to belong to the genus Halomonas in the class Gammaproteobacteria. Its closest relatives are Halomonas axialensis and Halomonas meridiana (98\% similarity). DNA-DNA hybridizations indicated that the novel isolate is genotypically distinct from these species. The DNA G + C content of the strain is $54.4 \mathrm{~mol} \%$. The main fatty acids $\left(\mathrm{C}_{18: 1} \omega 7 \mathrm{c}, 2-\mathrm{OH}\right.$ iso- $\mathrm{C}_{15: 0}, \mathrm{C}_{16: 0}$ and/or $\mathrm{C}_{19: 0}$ cyclo $\left.\omega 8 \mathrm{c}\right)$, main polar lipids (diphosphatidylglycerol, phosphatidylglycerol, phosphatidylethanolamine, phosphatidylcholine and an unidentified phosphoglycolipid) and major respiratory quinone (ubiquinone Q9) were determined. The novel isolate is heterotrophic, mesophilic, euryhaline (growth optimum ranging from 2 to $8 \% \mathrm{w} / \mathrm{v} \mathrm{NaCl}$ ) and is able to grow under stressful conditions. The strain accumulates poly- $\beta-$ hydroxyalkanoates granules and compatible solutes. Based on genotypic, chemotaxonomic and phenotypic distinctiveness, this isolate is likely to represent a novel species, for which the name Halomonas lionensis is proposed. The type strain of $\mathrm{H}$. lionensis is $\operatorname{RHS}^{\top}{ }^{\top}$ (DSM $25632^{\top}=\mathrm{CIP}$ $110370^{\top}=$ UBOCC $3186^{\top}$ ).
\end{abstract}

Keywords : Halomonas ; Taxonomy ; Environmental adaptation ; Metal tolerance ; Poly- $\beta$ hydroxyalkanoate ; Compatible 


\section{Introduction}

At the time of writing, the genus Halomonas, within the class Gammaproteobacteria, encompasses more than 76 recognized species (Oren and Ventosa, 2013). It comprises mostly marine halophilic aerobic heterotrophs well known for their metabolic versatility (Arahal and Ventosa, 2006; De la Haba R. R. et al., 2011). Microorganisms belonging to the genus Halomonas were initially found in hypersaline environments such as the Dead Sea, hypersaline lakes, hypersaline soils and solar salterns (Vreeland et al., 1980; Franzmann et al., 1987; Mormile et al., 1999; Oueriaghli et al., 2013). Later, culture-based and molecular-based studies revealed that Halomonas microorganisms are also present in numerous nonhypersaline environments such as animal tissues (Romanenko et al., 2002), factories (Dobson and Franzmann, 1996), non-marine biofilms (Heyrman et al., 2002), human blood (Kim et al., 2010) and in environments considered as stressful from an anthropocentric point of view, such as highly polluted/alkaline waters (Berendes et al., 1996; Yang et al., 2010) and nonhypersaline ices from Antarctica (Reddy et al., 2003). The use of molecular techniques in microbial ecology has also enlarged the list of environments associated with Halomonas species, as they have been found in deep oceans (Takami et al., 1999), hydrothermal vents (Kaye and Baross, 2004b; Simon-Colin et al., 2008; Kaye et al., 2011), subsurface environments (Durbin and Teske., 2011) and crustal fluids and rocks (Santelli et al., 2008). Thus, members of the genus Halomonas are widespread in the biosphere and colonize common to extreme environments. This distribution suggests that these bacteria display broad physiological plasticity and metabolic versatility and have developed specific adaptations that allow them to maintain or grow under extreme physical (pressure), chemical (pollutants, high concentrations of metals) and energetic (starvation) conditions, thus allowing them to colonize a variety of habitats. 
For instance, different halophilic archaea and bacteria, including several Halomonas species, accumulate poly- $\beta$-hydroxyalkanoates (PHA) (carbon and energy storage materials) to cope with nutrient-depleted conditions (Simon-Colin et al., 2008; Kulkarni et al., 2011). Also, some halophilic strains develop specific osmoadaptation mechanisms to prevent molecular damage from cellular freezing and dehydration. These mechanisms include (i) transmembrane exchange of salts to balance osmotic pressure through specific membrane transport proteins and (ii) accumulation of protective compatible solutes such as betaine or ectoine. Halomonas species are known to accumulate compatible solutes by uptake and/or by synthesis (Zhu et al., 2011). Comparative genomic analyses have shown that gene clusters pha (responsible for PHA synthesis) and ect (responsible for ectoine synthesis) are subject to horizontal gene transfer (HGT) events within halophilic species and that the genomic organization of phaC (coding for PHA synthase) and $p h \mathrm{a} P$ (coding for phasin) is conserved in Halomonas elongata and Halomonas sp. TD01(Cai et al., 2011). This conservation suggests that selective pressure is exerted on these genes, which may be partly responsible for the adaptive success and colonization capabilities of Halomonas species.

Even though the metabolic diversity of several Halomonas species has been described, very few studies have focused on the capacity of these microorganisms to confront various physical, chemical and nutritional conditions. In this study, we report the isolation and physiological characterization of a novel Halomonas species, strain $\mathrm{RHS} 90^{\mathrm{T}}$, isolated from Mediterranean Sea sediments, which exhibits wide physiological flexibility. 


\section{ACCEPTED MANUSCRIPT}

\section{Materials and methods}

\subsection{Bacterial isolation}

In October 2008, a sediment core was recovered in the Gulf of Lions $\left(42^{\circ} 41^{\prime} .596 \mathrm{~N}\right.$, 03 $50^{\circ} .493 \mathrm{E}$; water depth: $291 \mathrm{~m}$ ), in the western Mediterranean Sea and subsampled for microbiological analyses, as described elsewhere (Ciobanu et al., 2012). A sediment sample from $84 \mathrm{~cm}$ below the seafloor was spread on an agar plate composed of modified R2A medium (Ciobanu et al., 2012) and then incubated at $25{ }^{\circ} \mathrm{C}$. After 10 days of incubation, a beige colony was picked, purified by repeated streaking on marine agar 2216 (MA; Difco) plates and referenced as strain $\mathrm{RHS} 90^{\mathrm{T}}$. Stock cultures were stored at $-80^{\circ} \mathrm{C}$, in marine broth 2216 (MB, Difco) supplemented with 5\% (v/v) DMSO, until characterization.

\subsection{Culture conditions}

Unless stated otherwise, cultures were carried out aerobically in sterile MB 2216 medium (Difco) aliquoted into $50 \mathrm{~mL}$ vials or $10 \mathrm{~mL}$ aerobic tubes. Fifty or $25 \mu \mathrm{L}$ of an overnight preculture were inoculated in $10 \mathrm{~mL}$ of MB 2216 medium and then incubated at $30{ }^{\circ} \mathrm{C}$ in the dark with shaking at 90 or $100 \mathrm{rpm}$. All solutions and media used for microbiological experiments were sterile and all reagents used for molecular biology experiments were of molecular biology grade.

\subsection{Growth monitoring}

Growth of strain RHS90 ${ }^{\mathrm{T}}$ was routinely monitored by optical density measurement and ATP assay. The correlation $\left(n=81, r^{2}=0.92\right)$ between cell counting and optical density was determined by measuring the optical density at $600 \mathrm{~nm}$ of cultures diluted at different dilution factors $\left(1 / 10^{\text {th }}, 1 / 100^{\text {th }}, 1 / 1,000^{\text {th }}\right)$ with a spectrophotometer (Genesys 20 , Thermo Scientific). The same diluted cultures were counted in parallel in a modified Thoma chamber (depth 10 
$\mu \mathrm{m}$, Preciss Europe). The ATP content of cultures was determined with a Kikkoman Lumitester C-110 (Isogen Life Science) using the Bac Titer-Glo Microbial Cell Viability assay (Promega) according to the manufacturer's instructions with a few modifications: $75 \mu \mathrm{L}$ of culture and $75 \mu \mathrm{L}$ BacTiter-Glo buffer were used; internal calibration was performed with $10 \mu \mathrm{L}$ of a $100 \mathrm{nM}$ ATP solution and maximal fluorescence emissions values were considered.

\subsection{Microscopic observations of PHA inclusions and viability assay}

Cells were observed with a phase-constrast light microscope (Olympus BX60) at 40x and 100x magnifications. PHA cytoplasmic inclusions were stained with oxazine dye Nile Blue A following a modified procedure of the Gram-negative viable-colony staining technique of Spiekermann (Spiekermann et al., 1999): $0.5 \mu \mathrm{g}$ Nile Blue A (Sigma) were added per $\mathrm{mL}$ of liquid culture medium. After one day of cultivation, cells were observed under ultraviolet light with an epifluorescence microscope (Olympus BX60). Escherichia coli CM237 ${ }^{\mathrm{T}}$, which does not produce PHA, was used as a negative control. Cell viability and structural integrity of cultures grown under high hydrostatic pressure were determined using the LIVE/DEAD® BacLight Bacterial Viability kit (Invitrogen). A volume of $200 \mu \mathrm{L}$ culture exposed to $60 \mathrm{MPa}$ hydrostatic pressure for $9 \mathrm{~h}$ was stained in the dark for 15 min with $3 \mu \mathrm{L}$ propidium iodide/SYTO®9 (Invitrogen) and then observed under UV. Scanning electron microscopy (FEI Quanta 200) observations of cultures were done with standard HMDS-based (HexaMethylDiSilasane) preparation. Transmission electron microscopy (Jeol JEM 100 CX II) observations were made after negative staining with uranyl acetate $(2 \% \mathrm{v} / \mathrm{v})$.

\subsection{Determination of optimal growth parameters}


Determinations of temperature, $\mathrm{pH}$ and $\mathrm{NaCl}$ ranges for growth were performed in triplicate in $10 \mathrm{~mL}$ aerobic tubes incubated with shaking (90 or $100 \mathrm{rpm}$ ) in the dark. Growth rates were calculated using linear regression analysis of 5 to 9 points along the linear portions of the logarithmically transformed growth curves. Determinations of the temperature, $\mathrm{NaCl}$ concentration and $\mathrm{pH}$ ranges for growth were tested over the range $4-45^{\circ} \mathrm{C}\left(4{ }^{\circ} \mathrm{C}, 10{ }^{\circ} \mathrm{C}, 16\right.$ ${ }^{\circ} \mathrm{C}, 22{ }^{\circ} \mathrm{C}, 30{ }^{\circ} \mathrm{C}, 37{ }^{\circ} \mathrm{C}, 40{ }^{\circ} \mathrm{C}, 43{ }^{\circ} \mathrm{C}$ and $45{ }^{\circ} \mathrm{C}$ ) at pH 7 and with $2 \%$ (w/v) $\mathrm{NaCl}$ for temperature determination; over the range $0-30 \%(\mathrm{w} / \mathrm{v}) \mathrm{NaCl}(0 \%, 0.5 \%, 2 \%, 4 \%, 6 \%, 8$ $\%, 15 \%, 20 \%$ and $30 \%$ ) at $20{ }^{\circ} \mathrm{C}$ and $\mathrm{pH} 7$ for $\mathrm{NaCl}$ concentration analysis; and over the range $\mathrm{pH} 3-11(3,3.5,4,5,6,7,8,9,10$ and 11$)$ at $20{ }^{\circ} \mathrm{C}$ and with $2 \% \mathrm{NaCl}$ for $\mathrm{pH}$ determination. Exposure to hydrostatic pressure $(0.1,20,40,50$ and $60 \mathrm{MPa})$ was done in 0.6 L autoclaves (TopIndustrie, Vaux le Penil, France), in triplicate, at room temperature, with 5 mL syringes containing $3 \mathrm{~mL} \mathrm{MB}$ medium and $1 \mathrm{~mL}$ tetradecafluorohexane (Sigma Aldrich) to facilitate oxygen diffusion. .

\subsection{Substrate utilization}

To investigate the capacity of the strain to catabolize different substrates as sole carbon and energy sources with oxygen as a terminal electron acceptor, the strain was grown in the dark on the mineral basis of MB medium (depleted of all carbon and energy sources) supplemented with one substrate for each test. Carbon utilization tests were performed at concentrations of $1 \mathrm{mM}$ for amino acids, $1 \mathrm{mM}$ for organic acids, $1 \%(\mathrm{w} / \mathrm{v})$ for alcohols and $10 \mathrm{mM}$ for sugars except for cellulose, $\mathrm{D}(+)$ cellobiose, dextrin, $\mathrm{D}(+)$ galactose, poly$\mathrm{D}(+)$ galacturonic acid, $\mathrm{D}(-)$ fructose, $\mathrm{D}(+)$ lactose, pectin and xylan, which were all tested at 1 g.L $\mathrm{L}^{-1}$. Tween 80 degradation was investigated on Noble agar (Sigma-Aldrich) plates prepared with the mineral basis of MB medium and covered with the substrate $(0.75 \mathrm{mM})$. The ability of the strain to grow anaerobically and to ferment complex organic matter or carbohydrates 
(yeast-extract 1 g.L $\mathrm{L}^{-1}$, peptone 5 g.L $\mathrm{L}^{-1}$ and glucose $10 \mathrm{mM}$ ) was investigated under an $\mathrm{N}_{2}$ atmosphere (100\% w/v) on an MB mineral basis degassed and reduced with $0.05 \%$ (w/v) $\mathrm{Na}_{2} \mathrm{~S} 9 \mathrm{H}_{2} \mathrm{O}$. The ability of the strain to reduce nitrate, nitrite, sulfate or DMSO was investigated on an $\mathrm{MB}$ mineral basis prepared with $10 \mathrm{mM}$ nitrate, $10 \mathrm{mM}$ nitrite, $10 \mathrm{mM}$ sulfate or $10 \mathrm{mM}$ DMSO, respectively, and reduced with $10 \mu \mathrm{L}$ of $\mathrm{Na}_{2} \mathrm{~S}_{2} 9 \mathrm{H}_{2} \mathrm{O} 5 \%(\mathrm{v} / \mathrm{v})$. Aminomonas paucivorans (DSM $12260^{\mathrm{T}}$ ) and Shewanella profunda (DSM $15900^{\mathrm{T}}$ ), which are respectively fermentative and nitrate-reducing microorganisms, were used as positive controls for fermentation and nitrate reduction tests. The utilization of amino acids as sole nitrogen sources was tested in artificial sea water with fumarate and $\mathrm{D}(-)$ fructose $(2 \mathrm{mM}$ each) as carbon sources.

\subsection{Growth under oligotrophic conditions}

The capacity of strain RHS $90^{\mathrm{T}}$ to grow under oligotrophic conditions was investigated in duplicate with $20 \mathrm{~mL}$ of late-exponential phase cultures centrifuged at $6000 \mathrm{x} g$ for $15 \mathrm{~min}$ at $4{ }^{\circ} \mathrm{C}$. Cell pellets were then washed and suspended in $200 \mathrm{~mL}$ artificial sea water $(\mathrm{pH}=6.8)$ and stored at $4{ }^{\circ} \mathrm{C}$ for 30 days. Cellular density and cellular activity were measured every 3 days by cell counting and by ATP content measurements as described above. To discriminate between hypothetical ATP released after cellular lysis and intracellular ATP representative of cellular activity, the extracellular ATP content was also measured: $1 \mathrm{~mL}$ of cells suspended in artificial sea water and stored at $4{ }^{\circ} \mathrm{C}$ was filtered onto $0.2 \mu \mathrm{m}$ syringe filters (Millipore) to retain cells and the total ATP content of the filtrate was measured as described above. The viability of stored cells was further evaluated by inoculation of $50 \mathrm{~mL}$ vials containing $10 \mathrm{~mL}$ MB 2216 medium with $1 \mathrm{~mL}$ of the stored suspension diluted at different factors $\left(1 / 100^{\text {th }}\right.$, $\left.1 / 1,000^{\text {th }}, 1 / 10,000^{\text {th }}, 1 / 100,000^{\text {th }}, 1 / 1,000,000^{\text {th }}\right)$ and then incubated as described above. 


\subsection{Metal exposure}

Tolerance to metal exposure of the novel isolate was investigated in triplicate in MB medium supplemented with different metals $\left[\mathrm{AgSO}_{4}, \mathrm{CdCl}_{2}, \mathrm{CrK}\left(\mathrm{SO}_{4}\right)_{2}, \mathrm{CuSO}_{4}, \mathrm{CoSO}_{4}\right.$, $\left.\mathrm{ZnSO}_{4}, \mathrm{MnSO}_{4}, \mathrm{CsCl}\right]$ at several concentrations $(0.0005,0.001,0.005,0.01$ and $0.05 \mathrm{mM}$ for $\mathrm{AgSO}_{4} ; 0.05,0.2,0.4,0.6$ and $0.8 \mathrm{mM}$ for $\mathrm{CdCl}_{2} ; 0.5,0.75,1,1.5$ and $2 \mathrm{mM}$ for $\mathrm{CrK}\left(\mathrm{SO}_{4}\right)_{2}$; 0.5, 1, 1.5, 2 and $2.5 \mathrm{mM}$ for $\mathrm{CuSO}_{4} ; 1,1.5,2$ and $2.5 \mathrm{mM}$ for $\mathrm{CoSO}_{4} ; 0.5,1,1.5,2,3$ and 4 $\mathrm{mM}$ for $\mathrm{ZnSO}_{4} ; 10,20,30,40,50$ and $60 \mathrm{mM}$ for $\mathrm{MnSO}_{4} ; 80,100,125,150$ and $200 \mathrm{mM}$ for $\mathrm{CsCl}$ ). Growth was monitored by ATPmetry after $12-15 \mathrm{~h}$ incubation at $30{ }^{\circ} \mathrm{C}$ with shaking (100 rpm). Minimal inhibitory concentrations (MICs) of metals were defined by the concentration of metals leading to the same ATP content as the inoculum after $12 \mathrm{~h}$ of incubation.

The multiresistant strain Cupriavidus metallidurans $\mathrm{CH} 34^{\mathrm{T}}$, used as a control, was $\begin{array}{lllll}\text { grown } & \text { in } & \text { DSMZ } & \text { medium } & \end{array}$ (http://www.dsmz.de/microorganisms/medium/pdf/DSMZ_Medium1.pdf) supplemented with different concentrations of metals. Its growth and MIC values were determined as described above.

\subsection{Chemotaxonomic analyses}

Chemotaxonomic analyses were performed on mid- to late-exponential phases of growth cultures grown for 1 day in $\mathrm{MB}$ medium at $30{ }^{\circ} \mathrm{C}$ with shaking (100 rpm). The determination of whole-cell fatty acid composition was made by the standard protocol of the Sherlock Microbial Identification System (MIDI Inc., Newark, NJ, USA) and separation of polar lipids was performed by two-dimensional silica gel thin layer chromatography followed by development of total lipids and specific functional groups, as described previously. The 
analysis of respiratory quinones was carried out by thin-layer chromatography and then HPLC, as described previously (Tindall et al., 1990).

\subsection{Susceptibility to antibiotics}

Susceptibility to ampicillin, vancomycin, streptomycin, chloramphenicol nitrofuratoin, nalidixic acid, erythromycin, ampicillin (diluted in ethanol), kanamycin, rifampicin (diluted in DMSO), penicillin $\mathrm{G}$ and tetracycline was investigated at 10,30 and $100 \mathrm{ng}$ at $30{ }^{\circ} \mathrm{C}$ on $\mathrm{MA}$ plates, using the diffusion disc method.

\subsection{RMN spectroscopy}

Intracellular accumulation of organic compatible solutes was analyzed on cells grown on a rich medium containing 1 g.L $\mathrm{L}^{-1}$ yeast extract and 5 g.L $\mathrm{L}^{-1}$ peptone on a mineral basis of $\mathrm{MB}$ medium prepared with or without $\mathrm{NaCl}$. It was studied by ${ }^{13} \mathrm{C} \mathrm{NMR}$ spectroscopy on $4 \mathrm{~L}$ of culture either with and without $\mathrm{NaCl} 12.5 \%(\mathrm{w} / \mathrm{v})$, incubated at $30{ }^{\circ} \mathrm{C}$ with shaking. Cells were harvested by centrifugation $\left(6,000 \times \mathrm{g}, 15 \mathrm{~min}\right.$ at $\left.4^{\circ} \mathrm{C}\right)$ in late-exponential growth phase. Cell pellets were suspended in $20 \mathrm{~mL}$ RNase-free water mixed with $80 \mathrm{~mL}$ absolute ethanol, and then shaken for $2 \mathrm{~h}$ at room temperature. These suspensions were then pelleted $(15,000 \mathrm{x} g$, 20 min at $4{ }^{\circ} \mathrm{C}$ ) and supernatants were transferred into $50 \mathrm{~mL}$ tubes before being dried in a rotary evaporator. One-dimensional ${ }^{13} \mathrm{C}$ NMR spectra were recorded at $25{ }^{\circ} \mathrm{C}$ on a BRUKER DRX 300 spectrometer equipped with a $5 \mathrm{~mm}$ QNP probehead 1H/13C/31P/19F. NMR analyses were performed on samples dissolved in $700 \mu 1 \mathrm{D}_{2} \mathrm{O}$ at $99.96 \%$. The spectra were obtained with BRUKER pulse programs, using standard pulse sequences of 2 s delay, a $30^{\circ}$ pulse and 5000 scans. Chemical shifts were expressed in ppm relative to TMS (tetramethylsilane) as an external reference. 


\subsection{DNA extraction and amplification}

Briefly, DNA was extracted after centrifugation (20 min, 10,000 x $g$ at $4^{\circ} \mathrm{C}$ ) of 10 and $20 \mathrm{~mL}$ of mid-log phase culture. The pellet was suspended in $1 \mathrm{~mL}$ buffer (Tris $100 \mathrm{mM}-\mathrm{pH} 8$, EDTA $50 \mathrm{mM}-\mathrm{pH} 8, \mathrm{NaCl} 100 \mathrm{mM}$ ) and cellular lysis was achieved with $50 \mu \mathrm{L}$ sarkosyl 20 $\%, 100 \mu \mathrm{L}$ SDS $10 \%$ and $20 \mu \mathrm{L}$ proteinase $\mathrm{K}$ at $20 \mathrm{mg} / \mathrm{mL}\left(1 \mathrm{~h}, 55^{\circ} \mathrm{C}\right)$. One $\mathrm{mL}$ phenol/chloroform/isomaylic acid (25/24/1; Sigma) was added and gently mixed with the lysis buffer. After centrifugation $\left(10,000 \times \mathrm{g}, 15 \mathrm{~min}\right.$ at $\left.4{ }^{\circ} \mathrm{C}\right)$, the aqueous phase was gently mixed with $1 \mathrm{~mL}$ chloroform (Carlo Erba) and centrifuged $\left(10,000 \times g, 15 \mathrm{~min}\right.$ at $\left.4{ }^{\circ} \mathrm{C}\right)$. The aqueous phase was then mixed with $400 \mu \mathrm{L}$ of sodium acetate $(3 \mathrm{M}, \mathrm{pH}=5.2)$ and a 0.8 volume of isopropanol. DNA pellet was precipitated $30 \mathrm{~min}$ at $-20{ }^{\circ} \mathrm{C}$, centrifuged $\left(15,000 \times \mathrm{g}, 10 \mathrm{~min}\right.$ at $\left.4{ }^{\circ} \mathrm{C}\right)$, dried and finally resuspended in $50 \mu \mathrm{L}$ DEPC water. Amplification by polymerase chain reaction (PCR) was performed with GoTaq ${ }^{\circledR}$ Flexi DNA polymerase (Promega), following the manufacturer's instructions. The $16 \mathrm{~S}$ rRNA gene was amplified with the Bac8F and Bac1492R primers (DeLong, 1992) using the following protocol: $3 \mathrm{~min}$ at $95{ }^{\circ} \mathrm{C} ; 30$ cycles of 1 min at $95{ }^{\circ} \mathrm{C}, 1$ $\min 30 \mathrm{~s}$ at $52{ }^{\circ} \mathrm{C}$ and $2 \mathrm{~min}$ at $72{ }^{\circ} \mathrm{C} ; 6 \mathrm{~min}$ at $72{ }^{\circ} \mathrm{C}$. The amplification of genes encoding ectoine synthase (ectC), PHA synthase (phaC) and phasin (phaP) was performed using degenerated oligonucleotide primers (Eurogentec) designed with Halomonas elongata sequences as references: ectc_R_141 (TAC-CGA-GAC-SCA-YAT-CCA-YT), ectc_F_7 (GTT-CGC-AAB-MTB-GAA-GAA-GC), phaC_F_767 (CGC-CCT-GGA-TCA-ACA-AGTAT), phaC_R_998 (CCG-ACA-CAG-TAG-CTC-AGC-AG), phaC_F_727 (AGC-ACC-GAGAAG-GTC-TTC-AA), phaC_R_1037 (CTG-GTC-AGG-TAG-GCC-ACT-GT), phaP_F_69 (CAA-TGC-CTT-GAT-GCT-GGA-C), phaP_R_251 (AGC-ATR-TGS-TTG-GAC-AGCTC). The program used for PCR amplification was the same as that described above except 
that the hybridization temperatures were $60{ }^{\circ} \mathrm{C}, 64{ }^{\circ} \mathrm{C}$ and $62{ }^{\circ} \mathrm{C}$ for gene ectC, phaP and phaC, respectively.

\subsection{Genotypic and phylogenetic analyses}

DNA-DNA hybridization experiments were performed by the Identification Service of the Deutsche Sammlung von Mikroorganismen und Zellkulturen (DSMZ, Braunschweig, Germany), with H. axialensis (DSM-15723) and H. meridiana (DSM-5425), using a Cary 100 Bio UV/VIS-spectrophotometer.

Blast-based research of most similar 16S rRNA sequences was done against the GenBank database and against the web-based EzTaxon-e server (Kim et al., 2012). Phylogenetic analyses were done with SeaView4 (Gouy et al., 2010) using the Muscle Multiple Alignment option to align sequences. Sequences of the nearest neighbors used to perform the alignment were imported from the Ribosomal Database Project (RDP) website (http://rdp.cme.msu.edu/). Phylogenetic trees were constructed using SeaView4 software, on the basis of Neighbor Joining and PhyML (GTR model) algorithms. The robustness of the inferred topologies was assessed by bootstrap analyses based on 1,000 replications. The 19 nucleotidic signatures of the family Halomonadaceae (Dobson and Franzmann, 1996) were manually invastigated with SeaView4 using the E. coli 16S rRNA gene as reference numbering (Accession number NR_102804). The 16S rRNA gene sequence of Halomonas lionensis RHS90 ${ }^{\mathrm{T}}$ was deposited in the GenBank/EMBL/DDBJ databases under the accession number HE661586.

The genomic DNA G+C content of the isolate was determined by the Identification Service of the DSMZ, by HPLC analysis. 


\section{Results and discussion}

\subsection{Genotypic and phylogenetic analyses}

Based on a BLASTN search against GenBank and the EzTaxon-e Server, the 16S rRNA gene of strain RHS $90^{\mathrm{T}}$ shared highest sequence similarity with Halomonas axialensis (97.96\%), Halomonas meridiana (98.03\%) and Halomonas aquamarina (97.89\%). The 19 nucletotidic signatures of the family Halomonadaceae defined by Dobson and Franzmann (1996) were also all found in RHS90 ${ }^{\mathrm{T}} 16 \mathrm{~S}$ rRNA gene. Phylogenetic analyses performed with this gene confirmed these results, positioning the novel isolate RHS90 ${ }^{\mathrm{T}}$ close to $H$. axialensis and H. meridiana, within the genus Halomonas, in the family Halomonadaceae, class Gammaproteobacteria (Fig. 1).

To further determine whether or not strain RHS $90^{\mathrm{T}}$ represents a novel species, DNADNA hybridizations were performed with the two closest relatives. Levels of DNA-DNA relatedness with $H$. axialensis and $H$. meridiana were $57.1 \%$ and $62.4 \%$, respectively, and were therefore below the threshold value of $70 \%$ for species delineation (Wayne et al., 1987), indicating that the novel isolate was likely a novel Halomonas species.

\subsection{Morphology}

Cells were rod-shaped, with a size of 4.4-2.2 $\times 0.8-0.6 \mu \mathrm{m} \quad(\mathrm{n}=30)$. They were motile. This motility feature is characteristic of the genus Halomonas as the vast majority of Halomonas species are flagellated.

\subsection{Physiological characteristics}

Strain RHS $90^{\mathrm{T}}$ is mesophilic and moderately alkaliphilic, since its optimal temperature is $30^{\circ} \mathrm{C}$ (upper limit $45^{\circ} \mathrm{C}$ and positive growth at $4^{\circ} \mathrm{C}$, the minimal tested temperature) and has a pH range from 6 to 10 (optimum 7-9). It has a euryhaline phenotype, growing at $\mathrm{NaCl}$ 
concentrations from $0 \%$ to $20 \% \mathrm{NaCl}(\mathrm{w} / \mathrm{v})$ with a wide optimum of $2 \%$ to $8 \%$. The strain was shown to be a heterotrophic and obligate aerobic bacterium. It was able to use the following substrates as sole energy and carbon sources, with $\mathrm{O}_{2}$ as a terminal acceptor: the carbohydrates $\mathrm{D}(-)$ fructose, $\mathrm{D}(-)$ ribose, sucrose, $\mathrm{D}(+)$ galacturonate, pectin, $\mathrm{D}(-)$ trehalose, $\mathrm{N}$ acetylglucosamine, and xylan; the alcohols glycerol and mannitol; the organic acids propionate, fumarate and succinate; the amino acids L-alanine, L-arginine, L-asparagine, Lglutamine, L-glutamate, L-methionine, L-proline, L-serine, L-valine, L-cysteine, L-glycine, L-leucine and L-aspartate; and creatine. The strain did not use nitrate and nitrite as terminal electron acceptors with lactate or acetate as the carbon source, which is in agreement with the fact that no amplification of the nirK and the nirS genes could be obtained. It respired neither sulfate nor DMSO. Growth was not observed under fermentative conditions. No amino acid could be used as sole nitrogen source. Its metabolic versatility regarding carbon and energy sources may allow the strain to use refractory organic matter and detrital macromolecules such as proteins, polypeptides and polysaccharides from dead marine organisms, that may become available to them. Strain RHS $90^{\mathrm{T}}$ presents a distinctive carbon source utilization profile compared with its closest relatives (Table 1): it cannot, for example, use glucose or ethanol as its sole carbon source, whereas $H$. axialensis, $H$. meridiana and $H$. aquamarina are able to use these compounds. On the contrary, strain $\mathrm{RHS} 90^{\mathrm{T}}$ is able to grow on a minimal medium with $\mathrm{D}(-)$ ribose, while its closest relatives cannot.

Similarly to numerous other Halomonas species, this euryhaline strain, isolated from a marine sediment with an interstitial water salinity of $4 \%$ (w/v) (Ciobanu et al., 2012), was able to grow under strict halophilic conditions. Indeed, it was shown to be able to grow at concentrations from 0 to $20 \% \mathrm{NaCl}$ and its upper and optimal salinities (2-8 \%) for growth were higher than the values generally accepted to discriminate halophilic from halotolerant microorganisms (optimum $\mathrm{NaCl}$ concentration $\geq 5 \%$; upper $\mathrm{NaCl}$ concentration $\geq 10 \%$ ) 
(Oren, 2008). Strain RHS90 ${ }^{\mathrm{T}}$ was also able to grow under high hydrostatic pressure. Its growth rate was optimal at atmospheric pressure, but was slightly affected by an increase in hydrostatic pressure up to $40 \mathrm{MPa}$ (Fig. 2). Above $40 \mathrm{MPa}$, its growth rate decreased sharply. When grown under 50 or $60 \mathrm{MPa}$, the growth rate of the novel isolate was about one fifth of its growth rate under atmospheric pressure, but microscopic observations confirmed that cells were still dividing. However, these cells were non-motile and exhibited atypical elongated cellular shapes. LIVE/DEAD® staining of cells exposed to high pressure demonstrated that cells remained intact and that membranes were not permeabilized (Fig. S1). Since its growth rate is higher under atmospheric pressure, this strain can be considered as piezotolerant. Even though $H$. meridiana has already been reported to be capable of growing under $55 \mathrm{MPa}$ (Kaye and Baross, 2004a), this is the first time that growth of a Halomonas species has been described under $60 \mathrm{MPa}$. Piezotolerant strains have already been described among Gammaproteobacteria and Halomonas species. For example, enrichment cultures under high pressure have already been performed and efficient growth of Halomonas-related organisms has been described under $30 \mathrm{MPa}$ (Takami et al., 1999). As the pressure of $60 \mathrm{MPa}$ is much higher than the pressure measured in situ, it can be hypothesized that strain RHS $90^{\mathrm{T}}$ would be capable of growing in deeper environments, at 6,000 $\mathrm{m}$ depth where hydrostatic pressure reaches this level of high pressure. The effects of hydrostatic pressure have already been studied in $H$. axialensis, $H$. meridiana and $H$. hydrothermalis, showing a change in membrane lipid composition and in the protein expression level (Kaye and Baross, 2004a). These properties may explain the fact that several Halomonas species have also been isolated from deep marine environments (Kaye et al., 2004b; Simon-Colin et al., 2008).

Antibiotics have many roles in natural environments, shaping microbial physiology such as motility or biofilm formation at low concentrations (Raaijmakers and Mazzola, 2012). Considering these multiple effects, we considered it would be interesting to find out whether 
the novel isolate was resistant to antibiotics. The strain presented variable sensitivities towards different antibiotics. On solid medium, it was sensitive to nalidixic acid, chloramphenicol, ampicillin, rifampicin and penicillin $\mathrm{G}$ at $10 \mathrm{ng}$, to streptomycin, kanamycin and tetracycline at $30 \mathrm{ng}$ and to vancomycin at $100 \mathrm{ng}$. The strain was resistant to nitrofurantin, erythromycin and ampicillin at $100 \mathrm{ng}$. This variability in antibiotic sensitivities of strain RHS90 ${ }^{\mathrm{T}}$ may reflect complex cellular communication mediated by diffusive secondary metabolites within natural communities.

\subsection{Fatty acids, polar lipids and quinone composition}

The main fatty acid component of strain $\mathrm{RHS} 90^{\mathrm{T}}$ was $\mathrm{C}_{18: 1} \omega 7 c(48.6 \%)$. The fatty acids $\mathrm{C}_{16: 1} \omega 7 c / \mathrm{C}_{15: 0}$ iso-2-OH (13\%), $\mathrm{C}_{16: 00}(11.9 \%), \mathrm{C}_{19: 0}$ cyclo $\omega 8 c(9.3 \%), \mathrm{C}_{12: 0} 3-\mathrm{OH}(6.3$ $\%$ ) and $\mathrm{C}_{17: 0}$ cyclo $(4.3 \%)$ were also present in significant proportions (Table S1). The polar lipid pattern indicated the presence of phosphatidylglycerol, diphosphatidylglycerol, phosphatidylethanolamine, one phosphoglycolipid, two glycolipids and two phospholipids (Fig. S2). The major respiratory quinone was ubiquinone 9 (90\%), which is the typical dominant quinone in Halomonas species. In a previous study, Franzman and Tindall (1990) showed that there was no clear distinction between the genera Halomonas and Deleya, 2 genera of the family Halomonadaceae, on the sole basis of respiratory quinones, polar lipids and fatty acid composition. All species of these genera were described as containing $\mathrm{C}_{16: 1}$ cis 9, $\mathrm{C}_{16: 0}, \mathrm{C}_{17: 0}$ cyclo, $\mathrm{C}_{18: 1}$ and $\mathrm{C}_{19: 0}$ cyclo $_{11-12}$ as major fatty acid components. Interestingly, $\mathrm{C}_{16: 1}$ cis 9 and $\mathrm{C}_{19: 0}$ cyclo $_{11-12}$ were not detected in strain $\mathrm{RHS} 90^{\mathrm{T}}$, although a $\mathrm{C}_{19: 0}$ cyclo $\omega 8 c$ fatty acid represented a significant proportion.

\subsection{Tolerance to metals}


Metals can have beneficial or deleterious effects on cells, mainly depending on which metal is considered and at what concentration. Metals become toxic for a cell when they disturb molecular and cellular functions and structures. In environments such as polluted sites or hydrothermal vents, metals can be present at high concentrations and can diffuse more rapidly into cells. Over their evolution, cells have developed strategies to overcome these problems (Nies, 2003) and the tree of life contains microorganisms with a range of metal sensitivities that are more or less adapted to metal-rich environments. To investigate the capacity of strain RHS90 ${ }^{\mathrm{T}}$ to grow in the presence of metals, the MICs of strain RHS $90^{\mathrm{T}}$ were determined for 9 metals and compared with the MICs of Cupriavidus metallidurans strain $\mathrm{CH} 34^{\mathrm{T}}$ (determined in this study), a highly metal-resistant bacterium (Mergeay et al., 1985), and to MICs of the model bacterium E. coli strain CM237 ${ }^{\mathrm{T}}$ determined by Mergeay et al. (2003) (Table 2). The novel isolate was highly sensitive to Ag (MIC: 0.01 $\mathrm{mM}$ ) and $\mathrm{Cd}$ (MIC: $0.75 \mathrm{mM}$ ), which inhibited its growth at very low concentrations, but grew very well at high concentrations of Cs (MIC: $200 \mathrm{mM}$ ). Strain RHS90 ${ }^{\mathrm{T}}$ was also particularly resistant to Mn (MIC: $60 \mathrm{mM}$ ). Metal MIC values of strain RHS90 ${ }^{\mathrm{T}}$ differed substantially from those of $C$. metallidurans $\mathrm{CH} 34^{\mathrm{T}}$ and from those of E. coli CM237 ${ }^{\mathrm{T}}$. They were higher overall than those of $E$. coli $\mathrm{CM} 237^{\mathrm{T}}$, but lower than those of $C$. metallidurans. This trend was observed after exposure to $\mathrm{Cd}, \mathrm{Cu}, \mathrm{Co}, \mathrm{Ni}$ and $\mathrm{Cs}$. However, strain RHS90 ${ }^{\mathrm{T}}$ had higher MIC for Mn than C. metallidurans $\mathrm{CH} 34^{\mathrm{T}}$ and $E$. coli $\mathrm{CM} 237^{\mathrm{T}}$, higher and lower MIC values for $\mathrm{Ag}$ than C. metallidurans and E. coli $\mathrm{CM} 237^{\mathrm{T}}$ respectively, and was as resistant to $\mathrm{Cr}$ as $C$. metallidurans.

Strain RHS90 ${ }^{\mathrm{T}}$ might possess specific mechanisms to detoxify cells of an excess of metals. In C. metallidurans str. $\mathrm{CH} 34^{\mathrm{T}}$, it has been shown that metal tolerance is conferred by different plasmid encoded-systems such as the czc (cobalt-zinc-cadmium) or cnr (cobaltnickel) tolerance systems (Nies, 2000; Monsieurs et al., 2011). These highly regulated 
systems involve the sensing of metals and gene expression activation in order to release metals into the extracellular medium through efflux pumps. Many Halomonas species have been reported to harbor plasmids of $\sim 600 \mathrm{Mbp}$ and $\sim 70 \mathrm{Mbp}$, as well as other extrachromosomal elements (Argandoña et al., 2003). These plasmids could be responsible for some of the adaptive advantages in the genus Halomonas, including tolerance to metals. Interestingly, plasmid extraction could be performed on cells of strain $\mathrm{RHS} 90^{\mathrm{T}}$, revealing one or several plasmids > $10 \mathrm{kbp}$ (data not shown) that might possibly be involved in metal tolerance. $\mathrm{CMI}$ values of strain $\mathrm{RHS} 90^{\mathrm{T}}$ were higher $(\mathrm{Ag}, \mathrm{Cu}, \mathrm{Cd})$ or comparable $(\mathrm{Co}$ and $\mathrm{Cr})$ to those previously determined for $H$. elongata and $H$. subglaciescola (Nieto et al., 1989), two organisms harboring $\sim 600 \mathrm{kbp}$ and $\sim 70 \mathrm{kbp}$ plasmids (Argandoña et al., 2003).

\subsection{Growth under oligotrophic conditions}

The isolation of Halomonas species and detection of Halomonas-related sequences from oligotrophic environments have been extensively described. For example, sediments from the Arctic and Antarctic seas, Mediterranean sea, deep-sea waters or deep-sea bed (Durbin and Teske, 2011; Kaye et al., 2011) have been shown to harbor representatives of the genus Halomonas. This widespread representation of Halomonas species in nutrient-depleted habitats raises questions about their adaptation to oligotrophic conditions and may reflect a strong capability to thrive in such conditions. In order to ascertain whether strain $\operatorname{RHS} 90^{\mathrm{T}}$ can survive in extremely nutrient-depleted environments, the strain was stored for 4 weeks in artificial sea water without any carbon source at $4{ }^{\circ} \mathrm{C}$ (Fig. 3). During this storage period, cellular density remained constant $\left(\sim 8.10^{6}\right.$ cells.mL $\left.\mathrm{mL}^{-1}\right)$. The viability of counted cells was demonstrated by the positive growth of starved cultures when these were transferred to nutrient-rich media (MB2216) inoculated with the stored cell suspension diluted from the $1 / 100^{\text {th }}$ to the $1 / 100,000^{\text {th }}$. Total ATP content (with $85-97 \%$ representing intracellular ATP) 
determination showed that cellular activity remained relatively constant after 15 days storage and dropped off sharply after 25 day storage. This can be explained by (i) a decrease in metabolic activity and/or (ii) a decrease in cell size, as was microscopically observed (data not shown). These results show that strain $\mathrm{RHS}^{\mathrm{T}} 0^{\mathrm{T}}$ remained viable and maintained its population size under extremely oligotrophic conditions and at low temperatures over a period of one month.

\subsection{Amplification of PHA synthesis genes}

Many prokaryotes respond to starvation or to imbalanced ratios between carbon and nitrogen through the accumulation of carbon substrates in the form of polyhydroxyalkanoate (PHA) granules. PHA metabolism relies mostly on PHA synthase (phaC), PHA depolymerase (phaZ) and phasin, a protein associated with PHA granule inclusions (Matsumoto et al., 2002). PHA granules are synthesized by phaC when carbon sources are abundant and used under starvation. The phasin gene is generally located upstream of phaC and this genomic organization is conserved in many Proteobacteria (Cai et al., 2011). It is likely that PHA accumulation confers a strong adaptive advantage in natural environments where carbon source concentrations fluctuate. To determine whether strain RHS $90^{\mathrm{T}}$ had the genetic potential to synthesize PHA granules, PCR amplifications of the phaC gene were performed on DNA extracts. A single stretch of 234 nucleotides was obtained with the primer pairs phaCF998- phaCR767. Sequence comparison showed that this sequence was highly similar to poly(R)-hydroxyalkanoic acid synthase of some other Halomonas species. The highest similarity (96\% identity) was shared with Halomonas sp. HAL1, Halomonas sp. GFAJ and Halomonas sp. TD01, isolated from a gold mine and from two salt lakes (California, USA and Xinjiang, China), respectively (Lin et al., 2011; Tan et al., 2011; Kim and Rensing, 2012). This suggests that the genome of strain RHS90 ${ }^{\mathrm{T}}$ encodes a PHA synthase gene. Four classes 
of PHA synthases have been described, differing in subunit numbers and product chainlengths (Cai et al., 2011). Phylogenetic reconstruction demonstrated that this sequence belongs to class I of $p h a C$ genes (Fig. S3). Class I $p h a C$ comprises enzymes with one subunit that synthesizes short chains (3-5 carbon atoms) and medium chains (6 - 14 carbon atoms). Interestingly, other phaC genes belonging to class I have been sequenced in Halomonas sp. TD01 and Halomonas elongata (Cai et al., 2011).

Intracytoplasmic granules of PHA were observed by microscopy after Nile Blue A staining, suggesting that the amplified phaC gene is functional and allows the synthesis of PHA.

\subsection{Production of ectoine}

Compatible solutes such as ectoine, hydroxyectoine, betaine or glutamate are commonly produced by halophilic microorganisms to adapt to osmotic pressure caused by high extracellular salt concentrations. These compatible solutes prevent molecular and cellular structures from dehydration or freezing (Zhu et al., 2011). In order to discover whether such compatible solutes are produced by strain $\mathrm{RHS} 90^{\mathrm{T}}$, the metabolites of cells grown in MB without or with $12.5 \% \mathrm{NaCl}$ were analyzed with nuclear magnetic resonance (NMR) spectroscopy (Fig. S4).

When grown in rich medium without $\mathrm{NaCl}$, cells did not accumulate ectoine (Fig. S4A). On the contrary, when cells were grown in rich medium supplied with $12.5 \% \mathrm{NaCl}$, peaks attributed to ectoine, glycine betaine and glutamate were detected and represented the vast majority of metabolites accumulated (Fig. S4B). These results demonstrate that ectoine is accumulated by biosynthesis under our hypersaline growth conditions and suggest that the genome of strain RHS $90^{\mathrm{T}}$ carries the ectoine biosynthetic pathway genes. Similar results were previously obtained with $H$. pantelleriense. Ectoin was indeed the most abundant compatible 
solute detected in $H$. pantelleriense when grown in rich medium, and hydroxyectoine, betaine, glycine and glutamate were also detected (Romano et al., 2001). The proportion of ectoine increased with increasing $\mathrm{NaCl}$ concentration. This phenomenon was observed in rich (yeastextract) medium but appeared less pronounced in minimal (glucose) medium (Romano et al., 2001). In another study, Zhu et al. (2011) showed that the presence of ectoine or hydroxyectoine increased the cellular growth of the halophile Halomonas ventosae DL $7^{\mathrm{T}}$ after both thermal and osmotic stresses.

In order to confirm that an ectoine synthase $(e c t C)$ encoding gene is indeed borne by the genome of strain RHS90 ${ }^{\mathrm{T}}$, PCR amplifications were performed. Unfortunately, no positive amplification could be obtained. This lack of amplification may be attributed to the use of a non-specific primer, since primer sequences were determined on the basis of the H. elongata ectC gene sequence (NCBI Accession number: YP_003897659). The corresponding regions might not be conserved in strain RHS90 ${ }^{\mathrm{T}}$, thus leading to mismatches. 
In conclusion, this study demonstrates the physiological plasticity of strain RHS90 ${ }^{\mathrm{T}}$. From the results of polyphasic taxonomic analysis and based on genetic, physiological and

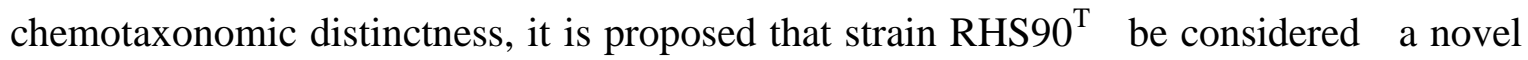
species within the genus Halomonas, for which the name Halomonas lionensis is proposed. This novel species presents interesting growth features, especially in terms of salinity, metal concentration and hydrostatic pressure tolerance. It has developed adaptive mechanisms based notably on PHA and ectoine accumulation, to overcome extreme

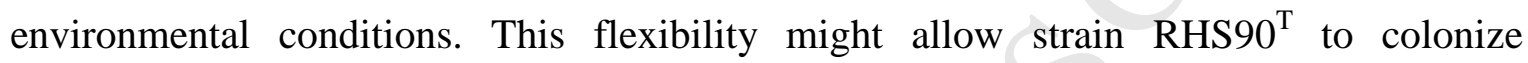
environments associated with a variety of environmental conditions and may be related to

Description of Halomonas lionensis sp. nov.

(li.on.en'sis. N.L. fem. adj. lionensis, of or belonging to Golfe du Lion [Gulf of Lions], in reference to the origin of the type strain).

Cells are Gram-negative, rod-shaped, motile, 0.7-2.5 $\mu \mathrm{m}$ in length $\mathrm{x}$ 0.4-1 $\mu \mathrm{m}$ in width. Colonies on MA are white, regularly circular, convex, translucent, smooth with an entire edge, creamy and do not produce exopolysaccharides. Grows aerobically at $\leq 4-45{ }^{\circ} \mathrm{C}$ with an optimum at $30{ }^{\circ} \mathrm{C}, \mathrm{pH}$ 6-10 with an optimum at 7-9 and with $\mathrm{NaCl}$ concentrations ranging 
fom $0-20 \%(\mathrm{w} / \mathrm{v})$ with an optimum at $2-8 \%$. Negative for nitrate and nitrite reduction, fermentation of peptone or yeast extract, Voges-Proskauer test and Methyl red test, indole formation, $\beta$-galactosidase (ONPG), arginine dihydrolase, gelatinase, $\beta$-glucosidase, lysine decarboxylase, ornithine decarboxylase, tryptophane deaminase, potassium gluconate assimilation, capric acid assimilation, adipic acid assimilation. Positive for urease, oxidase and catalase. The following substrates can be used as sole carbon source: citrate, fumarate, propionate, succinate, glycerol, D-mannitol, pectin, xylan, $\mathrm{D}(-)$ fructose, poly-D(+)galacturonic acid, N-acetylglucosamine, D(+)mannose, D(+)rhamnose, D(-)ribose, sucrose, D(-)trehalose, L-alanine L-arginine, L-asparagine, L-glutamate L-glutamine, Lglycine, L-leucine L-proline, L-serine, L-valine, creatine. The following substrates cannot be used as sole carbon source: collagen, elastine, keratine, tween 80, acetate, ascorbate, benzoate, betain, caprylate, citrate, formate, gluconate, hippurate, lactate, malate, malonate, tartrate, myo-inositol, ethanol, isopropanol, sorbitol, D-melezitose, threalose, L(+)arabinose, cellulose, dextrine, $\mathrm{D}(+)$ cellobiose, $\mathrm{D}(+)$ glucose, $\mathrm{D}(+)$ galactose, $\mathrm{D}(+)$ lactose, $\mathrm{D}(+)$ maltose, $\mathrm{D}(+)$ xylose, L-aspartate, L-cysteine, L-glycine, L-histidine, L-isoleucine, L-lysine, L-methionine, Lornithine, L-phenylalanine, L-threonine, L-tryptophane, L-tyrosine and L-valine. None of the 20 proteic amino acids can be used as sole nitrogen source.

The main fatty acids are $\mathrm{C}_{16}(11.85 \%), \mathrm{C}_{17: 00}$ cyclo (4.32 \%), $\mathrm{C}_{19: 0}$ CYCLO $\omega 8 c(9.32 \%)$, $\mathrm{C}_{18: 1} \omega 7 c(48.6 \%), 3-\mathrm{OH} \mathrm{C}_{12: 0}(6.25 \%)$ and $\mathrm{C}_{16: 1} \omega 7 c$ and/or $2-\mathrm{OH}$ iso- $\mathrm{C}_{15: 0}(13 \%)$. The main polar lipids are diphosphatidylglycerol, phosphatidylglycerol, phosphatidylethanolamine, phosphatidylcholine and an unidentified phosphoglycolipid. Ubiquinone 9 (Q-9) is the major quinone (90\%). The DNA G + C content is $54.4 \mathrm{~mol} \%$.

The type strain RHS $90^{\mathrm{T}}$ (DSM $25632^{\mathrm{T}}$, CIP $110370^{\mathrm{T}}$, UBOCC3186) was isolated from surficial sediments (84 $\mathrm{cm}$ below the seafloor) of the Gulf of Lions, in the western Mediterranean Sea. 
Acknowledgments

We thank the crew and chief scientists of the Rhosos and Esscar9 cruises aboard the

$\mathrm{R} / \mathrm{V}$ Le Suroit for core recoveries. The authors are grateful to Jean Euzéby for his comments about latin species names, Brian Tindall for constructive comments about chemotaxonomy,

Nelly Kervarec for NMR data acquisition, and Nadège Bienvenu and Claire Hémon for strain deposition in the UBO culture collection. Funding was supported by a PhD fellowhip from the Conseil Régional de Bretagne and the Université de Bretagne occidentale (UBO) to FG. MCC was supported by a postdoctoral fellowhip from the Ifremer-Institut Carnot. 
References

Arahal, D. R., Ventosa, A., 2006. The Family Halomonadaceae. In The Prokaryotes, pp. 811835. Edited by M. Dworkin S. Falkow E. Rosenberg K.-H. Schleifer \& E. Stackebrandt. Springer New York

Argandona, M., Martinez-Checa, F., Llamas, I., Quesada, E., Moral, A., 2003. Megaplasmids in Gram-negative, moderately halophilic bacteria. FEMS Microbiol. Lett. 227, 81-86

Berendes, F., Gottschalk, G., Heine-Dobbernack, E., Moore, E. R. B., Tindall, B. J., 1996. Halomonas desiderata sp. nov, a new alkaliphilic, halotolerant and denitrifying bacterium isolated from a municipal sewage works. Syst. Appl. Microbiol. 19, 158-167

Cai, L., Aibaidula, G., Dong, X. R., Chen, J. C., Tian, W. D., Chen, G. Q., 2011. Comparative genomics study of poly- $\beta$-hydroxyalkanoates (PHA) and ectoine relevant genes from Halomonas sp. TD01 revealed extensive horizontal gene transfer events and coevolutionary relationships. Microb. Cell. Fact.10

Ciobanu, M-C., Rabineau, M. Droz, L, Révillon, S., Ghiglione, J-F., Dennielou, B., Jorry, SJ., Kallmeyer, J., Etoubleau, J., Pignet, P., Crassous, P., Vandenabeele-Trambouze, O., Laugier, J., Guégan, M., Godfroy, A., Alain, K., 2012. Sedimentological imprint on subseafloor microbial communities in Western Mediterranean Sea Quaternary sediments. Biogeosciences 9, 3491-3512

De la Haba R. R., Sanchez-Porro C., Marquez M.C. and Ventosa A., 2011. Taxonomy of Halophiles. In Extremophiles handbook Part 3, Springer. Tokyo: K. Horikoshi, 255-308

DeLong, E. F., 1992. Archaea in coastal marine environments. Proc. Natl. Acad. Sci. 89, $5685-5689$

Dobson., S. J., Franzmann P. D., 1996. Unification of the genera Deleya Baumann et al. 1983., Halomonas (Vreeland et al. 1980) and Halovibrio (Fendrich 1988) and the 
species Paracoccus halodenitrificans (Robinson and Gibbons 1952) into a single genus, Halomonas, and placement of the genus Zymobacter in the family Halomonadaceae. Int. J. Syst. Bacteriol. 46, 550-558

Durbin, A. M, Teske, A., 2011. Microbial diversity and stratification of South Pacific abyssal marine sediments. Env. Microbiol. 13, 3219-34

Franzmann, P. D., Burton, H. R., McMeekin, T. A., 1987. Halomonas subglaciescola, a new species of halotolerant bacteria isolated from Antarctica. Int. J. Syst. Bacteriol. 37, 2734

Franzmann, P. D., \& Tindall, B. J., 1990.. A chemotaxonomic study of members of the family Halomonadaceae. Syst. Appl. Microbiol. 13, 142-147

Gouy, M., Guindon, S., Gascuel, O., 2010. SeaView version 4, a multiplatform graphical user interface for sequence alignment and phylogenetic tree building. Mol. Biol. Evol. $27,221-224$

Heyrman, J., Balcaen, A., De Vos, P., Swings, J., 2002. Halomonas muralis sp. nov., isolated from microbial biofilms colonizing the walls and murals of the Saint-Catherine chapel Castle Herberstein, Austria.. Int. J. Syst. Evol. Microbiol. 52, 2049-2054

Kaye, J. Z., Baross, J. A., 2004a. Synchronous Effects of Temperature, Hydrostatic Pressure, and Salinity on Growth, Phospholipid Profiles, and Protein Patterns of Four Halomonas Species Isolated from Deep-Sea Hydrothermal-Vent and Sea Surface Environments. Appl. Env. Microbiol. 70, 6220-6229

Kaye, J. Z., Márquez, M. C., Ventosa, A., Baross, J. A., 2004b. Halomonas neptunia sp. nov., Halomonas sulfidaeris sp. nov., Halomonas axialensis sp. nov. and Halomonas hydrothermalis sp. nov.: halophilic bacteria isolated from deep-sea hydrothermal-vent environments. Int. J. Syst. Evol. Microbiol. 54, 499-511 
Kaye, J. Z., Sylvan, J. B., Edwards, K. J., Baross, J. A., 2011. Halomonas and Marinobacter ecotypes from hydrothermal vent, subseafloor and deep-sea environments. Microb. Ecol. 75, 123-133

Kim, K. K., Lee, K. C., Oh, H. M., Lee, J. S., 2010. Halomonas stevensii sp. nov., Halomonas hamiltonii sp. nov. and Halomonas johnsoniae sp. nov., isolated from a renal care centre. Int. J. Syst. Evol. Microbiol. 60, 369-377

Kim, E-H., Rensing, C., 2012. Genome of Halomonas Strain GFAJ-1, a Blueprint for Fame or Business as Usual. J. Bacteriol. 194, 1643-1645

Kim OS, Cho YJ, Lee K, Yoon SH, Kim M, Na H, et al. 2012. Introducing EzTaxon-e: a prokaryotic 16S rRNA Gene sequence database with phylotypes that represent uncultured species. Int J Syst Evol Microbiol 62:716-21.

Kulkarni, S. O., Kanekar, P. P., Joq, J. P., Nilegaonkar, S. S., Sarnaik, S. S., Kshirsagar, P. R. 2011. Characterisation of copolymer, poly hydroxybutyrate-co-hydroxyvalerate (PHBco-PHV) produced by Halomonas campisalis MCM B-1027., its biodegradability and potential application. Biores. Technol. 102, 6625-6628

Lin, Y., Fan, H., Hao, X., Johnstone, L., Hu, Y., Wei, G., Alwathnani, H A., Wang, G., Rensing, C., 2011. Draft Genome Sequence of Halomonas sp. Strain HAL1, a Moderately Halophilic Arsenite-Oxidizing Bacterium Isolated from Gold-Mine Soil. J. Bacteriol. 194, 199-200

Matsumoto, K., Matsusaki, H., Taguchi, K., Seki, M., Doi, Y., 2002. Isolation and Characterization of Polyhydroxyalkanoates Inclusions and Their Associated Proteins in Pseudomonas sp. 61-3. Biomacromol. 3, 787-792

Mergeay, M., Nies, D., Schlegel, H. G., Gerit, J., Charle, P., Van Gijsegem, F., 1985. Alcaligenes eutrophus $\mathrm{CH} 34$ is a facultative chemolithotroph with plasmid-bound resistance to heavy metals. J. Bacteriol. 162, 328-334 
Mergeay, M., Monchy, S., Vallaey, T., Auquier, V., Benotmane, A., Bertin, P., Taghavi, S., Dunn, J., Lelie, D., Wattiez, R., 2003. Ralstonia metallidurans, a bacterium specifically adapted to toxic metals: towards a catalogue of metal-responsive genes. FEMS Microbiol. Rev. 27, 385-410

Monsieurs, P., Moors, H., Houdt, R., Janssen, P. J., Janssen, A., Coninx, I., Mergeay, M., Leys, N. 2011. Heavy metal resistance in Cupriavidus metallidurans CH34 is governed by an intricate transcriptional network. BioMetals $24,1133-1151$

Mormile, M. R., Romine, M. F., Garcia, M. T., Ventosa, A., Bailey, T. J., Peyton, B. M., 1999. Halomonas campisalis sp. nov., a Denitrifying, Moderately Haloalkaliphilic Bacterium. Syst. Appl. Microbiol. 22, 551-558

Nies, D. H., 2000. Heavy metal-resistant bacteria as extremophiles molecular physiology and biotechnological use of Ralstonia sp. CH34.Extremophiles 4, 77-82

Nies, D. H., 2003. Efflux-mediated heavy metal resistance in prokaryotes. FEMS Microbiol. Rev. 27, 313-339

Nieto, J. J., Fernandez-Castillo, R., Marquez, M. C., Ventosa, A., Quesada, E., RuizBerraquero, F., 1989. Survey of metal tolerance in moderately halophilic eubacteria. Appl. Env. Microbiol. 55, 2385-2390

Oren, A., 2008. Microbial life at high salt concentrations: phylogenetic and metabolic diversity. Saline Syst. 4, 2

Oren, A. and Ventosa, A. 2013. Subcommittee on the taxonomy of Halobacteriaceae and Subcommittee on the taxonomy of Halomonadaceae Int. J. Syst. Evol. Microbiol. 63: $3540-3544$.

Oueriaghli, N., González-Domenech, C., Martínez-Checa, F., Muyzer, G., Ventosa, A., Quesada, A., Béjar, V. 2013. Diversity and distribution of Halomonas in Rambla 
Salada, a hypersaline environment in the southeast of Spain. FEMS Microbiol. Ecol. 87: 460-474

Raaijmakers, J. M., Mazzola, M., 2012. Diversity and Natural Functions of Antibiotics Produced by Beneficial and Plant Pathogenic Bacteria. Ann. Rev. Phytopathol. 50, 403424

Reddy, G., Raghavan, P., Sarita, N., Prakash, J., Nagesh, N., Delille, D., Shivaji, S., 2003. Halomonas glaciei sp. nov. isolated from fast ice of Adelie Land, Antarctica. Extremophiles 7, 55-61

Romanenko, L. A., Schumann, P., Rohde, M., Mikhailov, V. V., Stackebrandt, E., 2002. Halomonas halocynthiae sp. nov., isolated from the marine ascidian Halocynthia aurantium. Int. J. Syst. Evol. Microbiol. 52, 1767-1772

Romano, I., Nicolaus, B., Lama, L., Trabasso, D., Caracciolo, G., Gambacorta, A., 2001. Accumulation of Osmoprotectants and Lipid Pattern Modulation in Response to Growth Conditions by Halomonas pantelleriense. Syst. Appl. Microbiol. 24, 342-352

Santelli, C. M., Orcutt, B. N., Banning, E., Bach, W., Moyer, C. L., Sogin M. L., Staudigel, H., Edwards, K. J., 2008. Abundance and diversity of microbial life in ocean crust. Nature 453, 653-656

Simon-Colin, C., Raguénès, G., Cozien, J., Guezennec, J. G., 2008. Halomonas profundus sp. nov., a new PHA-producing bacterium isolated from a deep-sea hydrothermal vent shrimp. J. Appl. Microbiol. 104, 1425-1432

Spiekermann, P., Rehm, B. H. A., Kalscheuer, R., Baumeister, D., Steinbüchel, A., 1999. A sensitive, viable-colony staining method using Nile red for direct screening of bacteria that accumulate polyhydroxyalkanoic acids and other lipid storage compounds. Arch. Microbiol. 171, 73-80 
Takami, H., Kobata., K., Nagahama, T., Kobayashi, H., Inoue, A., Horikoshi, K., 1999. Biodiversity in deep-sea sites located near the south part of Japan. Extremophiles 3, 97102

Tan, D., Xue, Y-S., Aibaidula, G., Chen, G-Q., 2011. Unsterile and continuous production of polyhydroxybutyrate by Halomonas TD01. BioresTechnol. 102, 8130-8136

Tindall, B., 1990. Lipid composition of Halobacterium lacusprofundi. FEMS Microbiol. Lett. 66, 199-202

Vreeland, R. H., Litchfield, C. D., Martin, E. L., Elliot, E., 1980. Halomonas elongata, a new genus and species of extremely salt-tolerant bacteria. Int. J. Syst. Evol. Microbiol. 30, $485-495$

Wayne, L. G., Brenner, D. J., Colwell, R. R., Grimont, P. A. D., Kandler, O., Krichevsky M. I., Moore, L. H., Moore, W. E. C., Murray, R. G. E., Stackebrandt, E., Starr, M. P., Trüper, H. G., 1987. Report of the ad hoc committee on reconcilliation of approaches to bacterial systematics. Int. J. Syst. Evol. Bacteriol. 37, 463-464

Yang, C., Wang, Z., Lin, Y., Niu, Y., Du, M., He, X., Ma, C., Tang, H., Xu, P., 2010. Metabolic versatility of halotolerant and alkaliphilic strains of Halomonas isolated from alkaline black liquor. Biores. Technol. 101, 6778-6784

Zhu, D., Wang, C., Hosoi-Tanabe, S., Zhang, W., Nagata, S., 2011. The synthesis and role of hydroxyectoine in halophilic bacterium Halomonas ventosae DL7. Afr. J. Microbiol. Res. 5, 2254-2260 
704

705

706

707

708

709

710

711

712

713

714

715

\section{Figure captions}

Fig. 1. Phylogenetic tree based on $16 \mathrm{~S}$ rRNA gene sequences showing the relationships

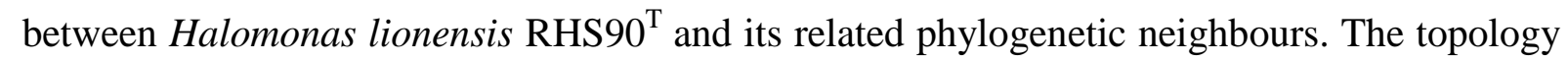
shown was calculated with the neighbour-joining algorithm. Accession numbers are indicated in brackets. Bootstrap values (\%) are indicated at the branch nodes and were calculated from 1000 resampled datasets. Chromohalobacter canadensis and Chromohalobacter israelensis were used as outgroups.

Fig. 2. Effects of hydrostatic pressure on the growth rate of strain RHS90 ${ }^{\mathrm{T}}$. Bars indicate standard deviation $(n=3)$.

Fig. 3. Cellular activity, as determined by total ATP content and cellular density of cells of strain RHS90 ${ }^{\mathrm{T}}$ stored in carbon source-depleted artificial sea water. The total and extracellular ATP contents of artificial sea water are represented by black and grey bars, respectively. Cellular densities determined by cell counts are shown by white squares. 
Tables

Table 1

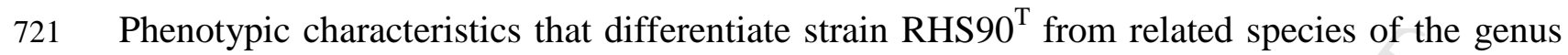

Halomonas.

\begin{tabular}{|c|c|c|c|c|}
\hline Characteristic & 1 & 2 & 3 & 4 \\
\hline Isolation source & Mediterranean Sea & Temperate & Cold hypersaline & Low temperature \\
\hline & sediments & ocean & lake & hydrothermal fluid \\
\hline Motility & $\mathrm{Y}$ & $\mathrm{Y}$ & 1 & $\mathrm{Y}$ \\
\hline Size $(\mu \mathrm{m})$ & $4.4-2.2 \times 0.8-0.6$ & $4-6 \times 0.4-0.6$ & $1.9-4.5 \times 0.6-1.0$ & ND \\
\hline Temperature range (opt) & $\leq 4-45(30)$ & $5-40(20-25)$ & $-5-45(28-40)$ & $-1-35(30)$ \\
\hline $\mathrm{pH}$ range (opt) & $6-10(7-9)$ & $5-10$ & $5-10$ & $5-12$ \\
\hline $\mathrm{NaCl}$ range \%w:v (opt) & $0-20(2-8)$ & $0-20(7.5-10)$ & $0.01-25(1-3)$ & $0.5-24(4)$ \\
\hline \multicolumn{5}{|l|}{ Hydrolysis of: } \\
\hline Tween 80 & - & + & + & - \\
\hline \multicolumn{5}{|l|}{ Growth with: } \\
\hline $\mathrm{L}(+)$ Arabinose & - & + & - & + \\
\hline D(-)Fructose & + & - & - & + \\
\hline $\mathrm{D}(+)$ Galactose & - & - & + & - \\
\hline $\mathrm{D}(+)$ Glucose & - & + & + & + \\
\hline $\mathrm{D}(+)$ Lactose & - & + & - & - \\
\hline $\mathrm{D}(+)$ Maltose & - & - & + & + \\
\hline D(-)Ribose & + & - & - & - \\
\hline Citrate & - & + & - & - \\
\hline Lactate & - & + & + & - \\
\hline Malonate & - & + & - & - \\
\hline Propionate & + & + & - & - \\
\hline Succinate & + & + & + & - \\
\hline Ethanol & - & + & + & + \\
\hline Glycerol & + & + & + & - \\
\hline Mannitol & + & + & - & - \\
\hline L-Alanine & + & + & + & - \\
\hline L-Arginine & + & - & ND & ND \\
\hline L-Asparagine & + & - & ND & - \\
\hline
\end{tabular}




\begin{tabular}{|lcccc|}
\hline L-Glutamine & + & - & ND & ND \\
L-Glutamate & + & - & - & + \\
Lysine & - & + & + & - \\
Proline & + & - & + & - \\
Serine & + & - & + & - \\
Valine & + & - & - & 54.4 \\
& & & & \\
DNA G+C content & 54.4 & $57-58$ & $58.2-59.9$ & \\
$($ mol \%) & & & & \\
\end{tabular}

Taxa: 1, strain RHS90 (this study); 2, H. aquamarina (Kaye et al. 2004; Arahal

and Ventosa 2006); 3, H. meridiana (Kaye et al. 2004; Arahal and Ventosa 2006) ; 4, H. axialensis (Kaye et al. 2004) ; +, Positive; -, Negative; ND, no data available; Y, Yes.

Table 2.

Comparison of Minimal Inhibitory Concentrations (MIC) of different metals for H. lionensis strain RHS90 ${ }^{\mathrm{T}}$, C. metallidurans $\mathrm{CH} 34^{\mathrm{T}}$ and E. coli $\mathrm{CM} 237^{\mathrm{T}}$.

\begin{tabular}{|c|c|c|c|c|c|c|c|c|c|}
\hline & $\mathrm{AgSO}_{4}$ & $\mathrm{CdCl}_{2}$ & $\mathrm{CrK}(\mathrm{SO4})_{2}$ & $\mathrm{CuSO}_{4}$ & $\mathrm{CoSO}_{4}$ & $\mathrm{NiCl}_{2}$ & $\mathrm{ZnSO}_{4}$ & $\mathrm{MnSO}_{4}$ & $\mathrm{CsCl}$ \\
\hline \multicolumn{10}{|l|}{ Halomonas lionensis } \\
\hline RHS90 $^{T}$ & 0.01 & 0.75 & 1.75 & 2 & 3 & 8 & 3 & 60 & 200 \\
\hline \multicolumn{10}{|c|}{ Cupriavidus metallidurans } \\
\hline $\mathrm{CH}_{34}{ }^{\mathrm{T}}$ & 0.0005 & 8 & 1.75 & 3 & 35 & 13 & 12 & 30 & 250 \\
\hline E.coli strain CM237 ${ }^{\mathrm{T} \text { a }}$ & 0.02 & 0.5 & 0.2 & 1 & 1 & 1 & 1 & 20 & 50 \\
\hline
\end{tabular}

Values are expressed in $\mathrm{mM}$.

${ }^{\text {a }}$ The MIC values of E. coli strain $\mathrm{CM} 237^{\mathrm{T}}$ correspond to those previously determined by Monsieur et al. (2011). 
Figures

Fig. 1.

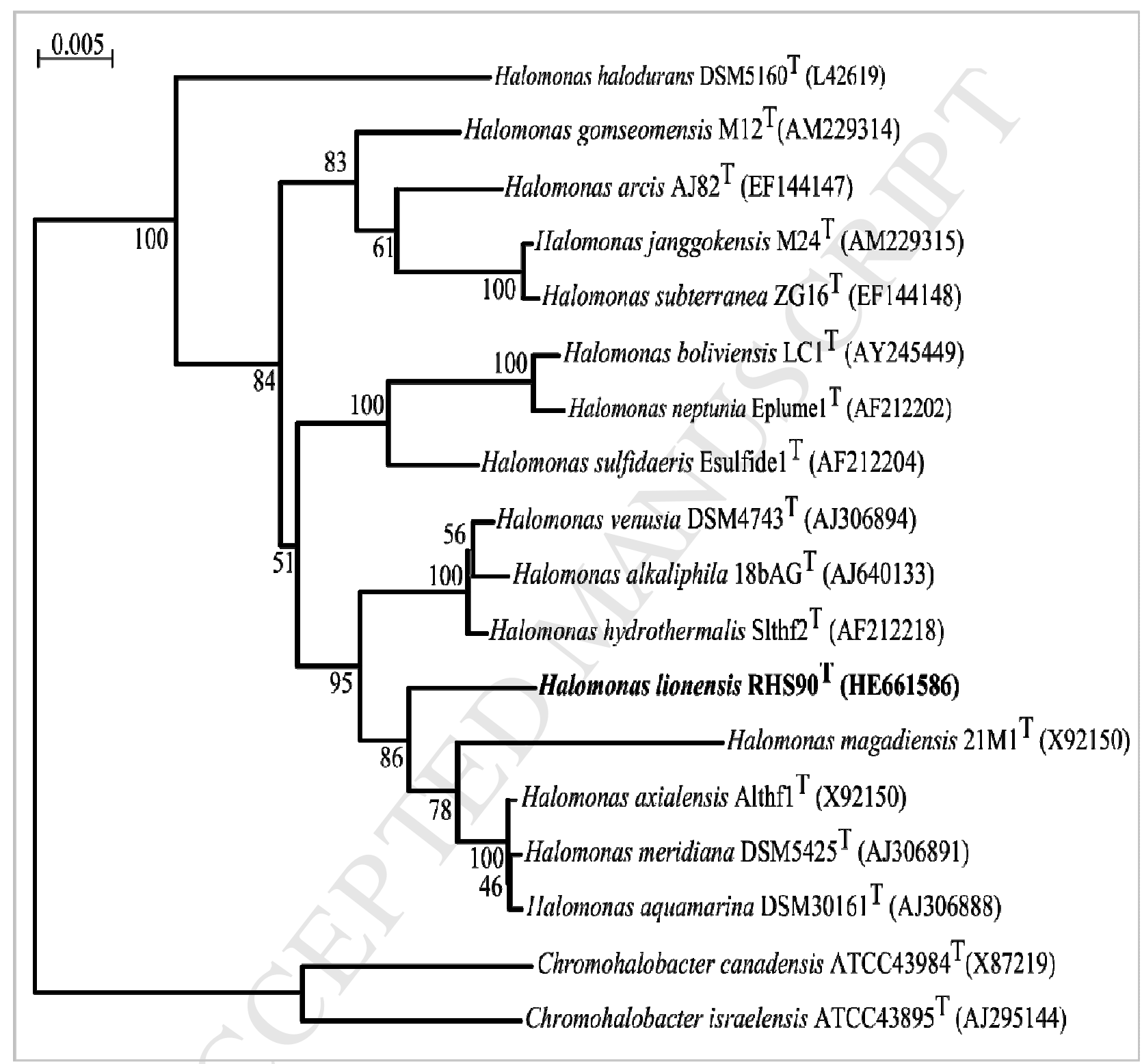


Fig. 2.
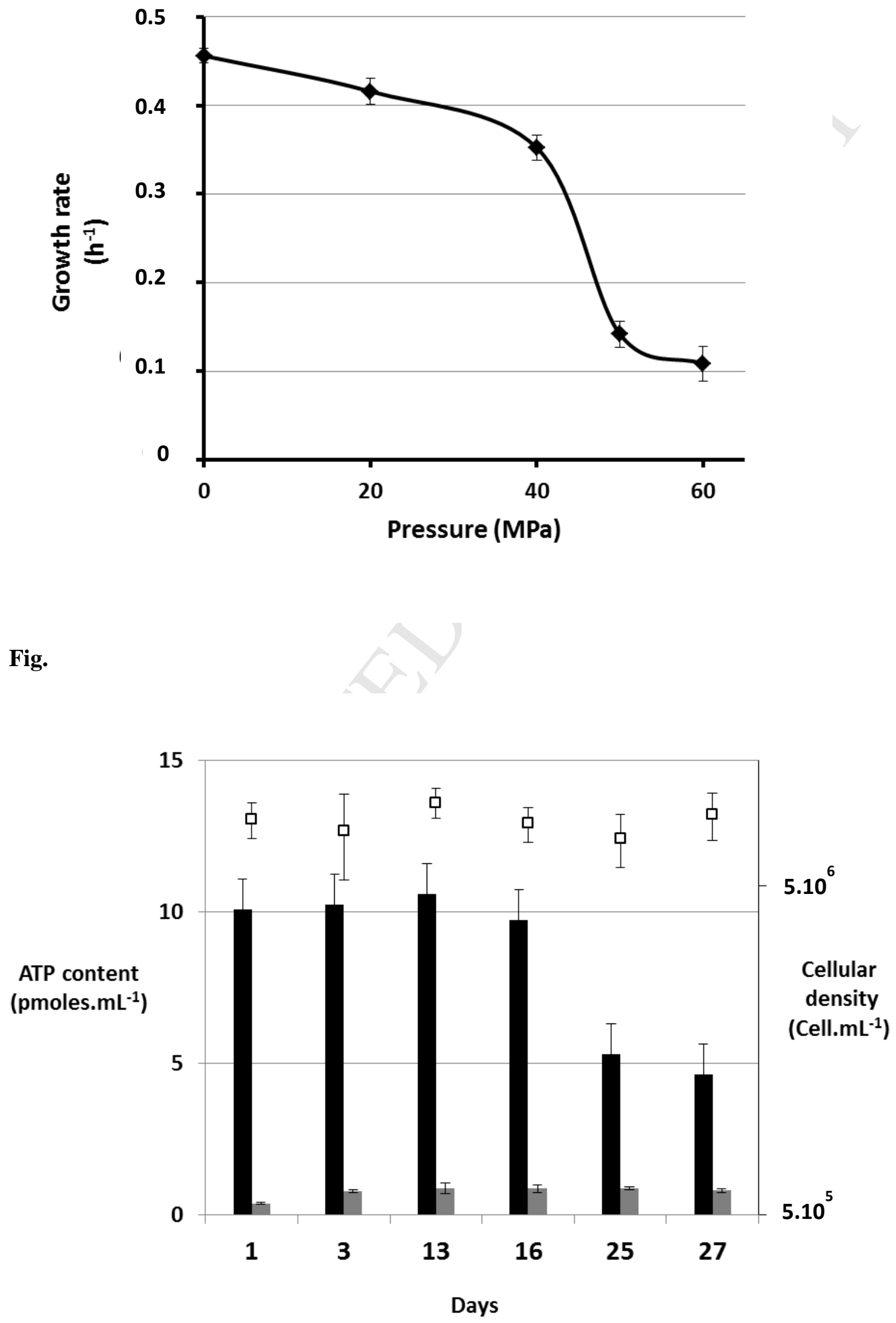


\section{Supplementary materials for on line submission}

A

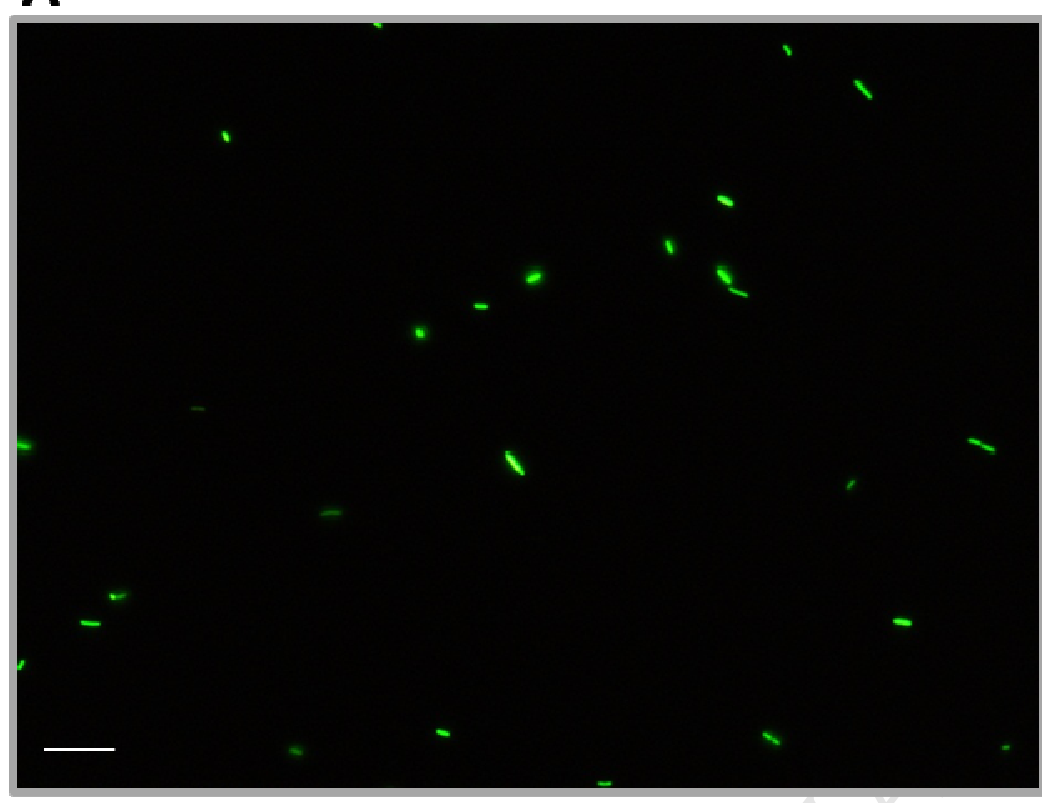

B

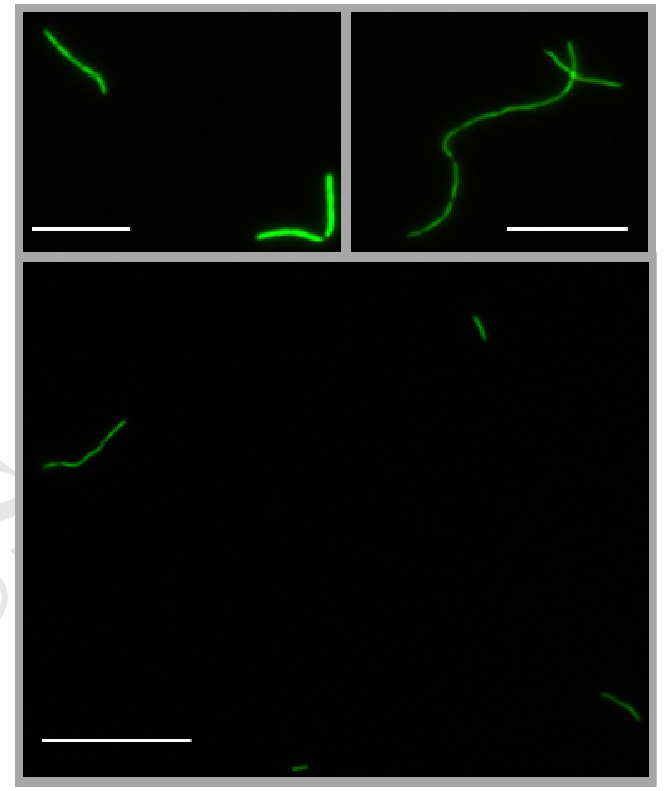

764 Fig. S1. UV-exposed micrographs of cells of strain RHS $90^{\mathrm{T}}$ incubated for 9 hours under atmospheric pressure (A) or under $60 \mathrm{MPa}(\mathrm{B})$ and stained with the LIVE/DEAD® BacLight ${ }^{\mathrm{TM}}$ Bacterial Viability mixture. 


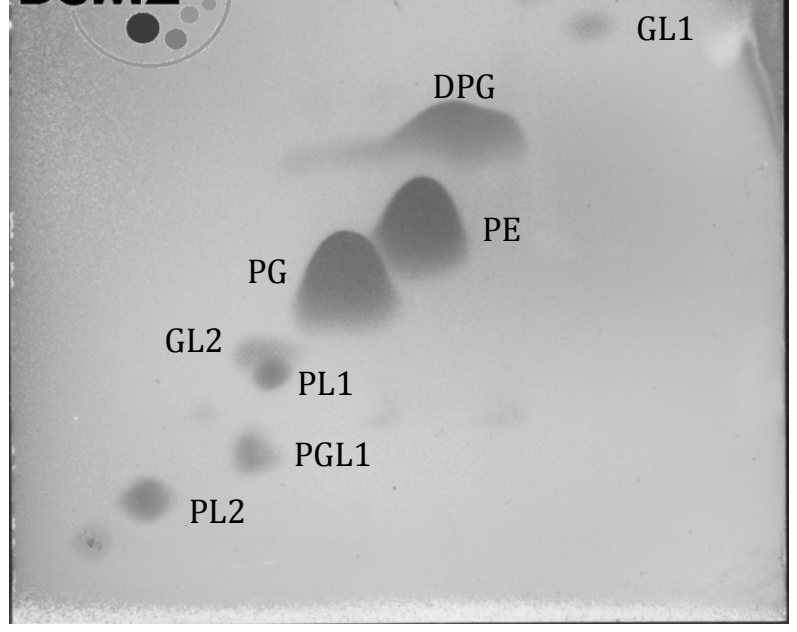

Fig. S2. Polar lipids of strain $\mathrm{RHS}^{\mathrm{T}}$ following separation by two-dimensional TLC. PE,

Glycolipids; PL1-PL2, Phospholipids; DPG, Diphosphatidylglycerol; PGL1, Phosphoglycolipids. 
778

779

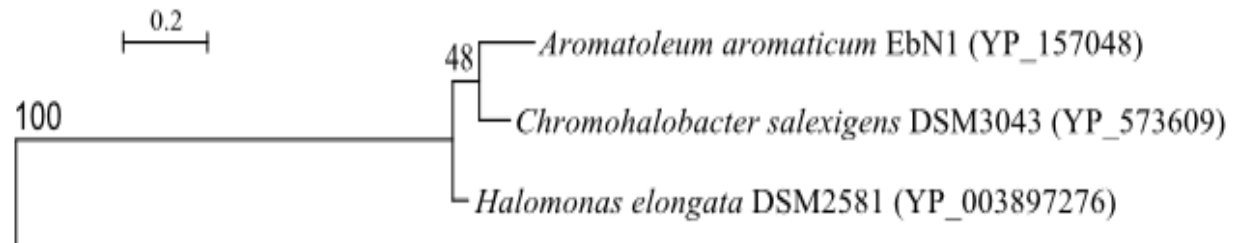

781

782

783

784

785

786

787

788

789

790

791

792

793

794

795

Ralstonia eutropha H16 (YP_725940)

2

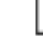

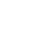

\section{6} 17 8 9 so

Fig. S3. Phylogenetic position of the putative phaC gene sequence of strain RHS90 ${ }^{\mathrm{T}}$.

A multiple alignment was made with ClustalW and the tree was constructed using the neighbourjoining algorithm of Seaview4. The GenBank accession numbers are given in brackets. 


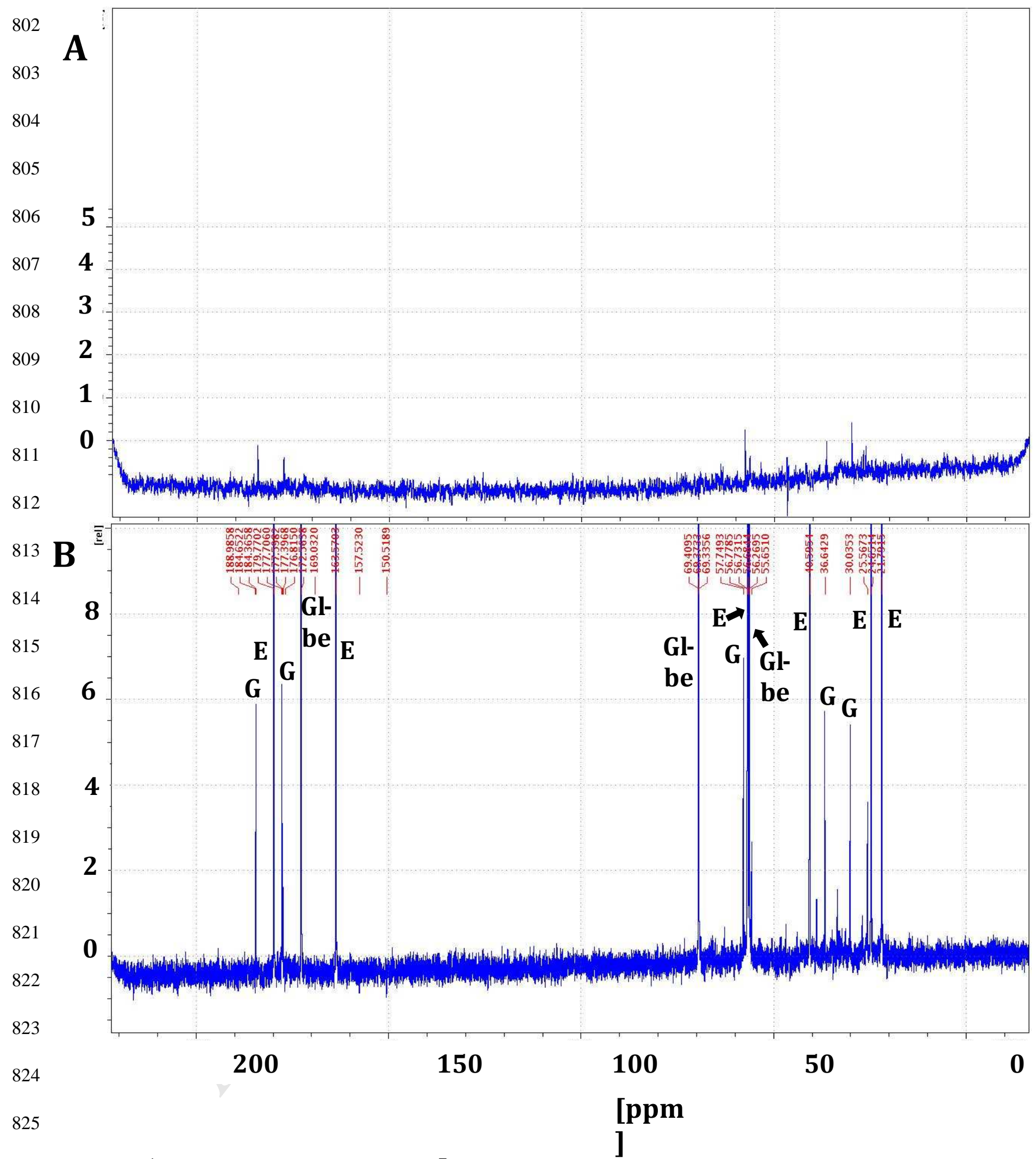

826 Fig. S4. ${ }^{1} \mathrm{H}-\mathrm{NMR}$ spectra of strain $\mathrm{RHS}^{\mathrm{T}} 0^{\mathrm{T}}$ grown without (A) or with (B) $12.5 \%$ (w/v) $\mathrm{NaCl}$. The

(E), glycine-betaine

(Gl-bt) and glutamate

(G). 
829 Table S1 Whole-cell fatty acid profile of strain $\mathrm{RHS}^{\mathrm{T}} 0^{\mathrm{T}}$ cells at mid-exponential growth 830 phase, cultivated on MB2216; $99.59 \%$ of the fatty acid peaks could be assigned by the 831 Sherlock Microbial Identification System (MIDI Inc, Newark, USA). Major fatty acids are 832 indicated in bold.

\begin{tabular}{|c|c|}
\hline $\begin{array}{l}\text { Fatty acid } \\
\text { Saturated }\end{array}$ & Proportion (\%) \\
\hline $\mathrm{C}_{10: 0}$ & 0.17 \\
\hline $\mathrm{C}_{12: 0}$ & 0.66 \\
\hline $\mathrm{C}_{14: 0}$ & 2.38 \\
\hline $\mathrm{C}_{16: 0}$ & 11.85 \\
\hline $\mathrm{C}_{17: 0}$ & 0.27 \\
\hline $\mathrm{C}_{17: 0} \mathrm{ISO}$ & 0.17 \\
\hline $\mathrm{C}_{17: 0} \mathrm{CYCLO}$ & 4.32 \\
\hline $\mathrm{C}_{18: 0}$ & 0.46 \\
\hline $\mathrm{C}_{19: 0}$ CYCLO $\omega 8 c$ & 9.32 \\
\hline Monounsaturated & \\
\hline $\mathrm{C}_{18: 1} \omega 7 c$ & 48.60 \\
\hline Hydroxy & \\
\hline $3-\mathrm{OH} \mathrm{C} 10: 0$ & 0.27 \\
\hline $3-\mathrm{OH} \mathrm{C} \mathrm{C}_{12: 0}$ & 6.25 \\
\hline $2-\mathrm{OH} \mathrm{C} \mathrm{C}_{18: 1}$ & 0.12 \\
\hline Methyl-substituted & \\
\hline 11-methyl $\mathrm{C}_{18: 1} \omega 7 c$ & 1.75 \\
\hline Summed featured & \\
\hline Summed feature $3^{a}$ & 12.99 \\
\hline Summed feature $7^{\mathrm{a}}$ & 0.54 \\
\hline
\end{tabular}


834 Legend: ECL, equivalent chain-length. ${ }^{\text {a }}$ Summed feature 3 contains $\mathrm{C}_{16: 1} \omega 7 c$ and/or 2-OH iso- $\mathrm{C}_{15: 0}$ 835 and summed feature 7 contains an unidentifed component with 18.846 ECL and/or ante- $\mathrm{C}_{19: 1} \omega 6 c$.

836

837

838 